\title{
THE INFLUENCE OF THINK-ALOUD STRATEGY AND READING INTEREST TOWARD READING COMPREHENSION STUDENTS OF ADAB FACULTY IAIN RADEN FATAH PALEMBANG
}

\author{
Nyayu Yayu Suryani *)
}

\begin{abstract}
Abstrak
Penelitian ini bertujuan untuk mengetahui apakah: (1) ada perbedaan yang signifikan dalam pemahaman membaca dengan menggunakan strategi think-aloud dan strategi konvensional; (2) ada perbedaan yang signifikan dalam pemahaman membaca antara strategi think-aloud dan teknik konvensional berdasarkan tingkat high level dalam minat membaca; (3) ada perbedaan yang signifikan dalam pemahaman membaca antara strategi think-aloud dengan menggunakan teknik konvensional berdasarkan tingkat low level dalam minat membaca; (4) ada pengaruh interaksi dari strategi yang digunakan dan minat baca yang diajarkan terhadap prestasi pemahaman membaca. Populasi penelitian adalah mahasiswa semester dua Fakultas Adab di IAIN Raden Fatah Palembang yang terdiri dari 248 siswa. Sampel penelitian ini adalah 84 mahasiswa dengan menggunakan random sampling. Metode penelitian ini adalah metode eksperimental. Penelitian ini dikategorikan dalam (low and high interest). Penelitian ini dapat disimpulkan bahwa: (1) terdapat perbedaan yang signifikan dalam pencapaian pemahaman membaca antara strategi Think-aloud dan strategi konvensional. (2) ada perbedaan yang signifikan dalam pencapaian pemahaman membaca antara strategi think-aloud dengan menggunakan teknik konvensional berdasarkan high interest dalam minat membaca. (3) ada perbedaan yang signifikan dalam pencapaian pemahaman membaca antara strategi think-aloud dengan menggunakan teknik konvensional berdasarkan low interest minat membaca. (4) ada pengaruh interaksi yang signifikan antara strategi think-aloud dan minat membaca terhadap pemahaman membaca.
\end{abstract}

\section{Kata kunci: Strategi Think-aloud, Minat Membaca, Pemahaman Membaca}

\section{BACKGROUND}

English as a foreign language is one of the most important subjects in most schools. Nowadays, English teaching in Indonesia is based on the genre the type of test. It has been begun since Competence-Based Curriculum was applied in 2004, then continued to School-Based Curriculum in 2006 and now 2013 Curriculum. The materials are delivered to students in contexts.
In the modern world, reading is one of the most important skills to acquire knowledge. Most of sciences have been spread through electronic or printed media, such as: TV, internet, books, and journals. According to Sharon (in Abdillah, 2003:1--2), $70 \%-95 \%$ of teaching and learning activities in the classroom depends on written texts like textbook. This means that learners should be good readers in order to comprehend what 
they read from text. In relation with teaching English as foreign language (TEFL), English teacher should motivate their students to read English text using appropriate strategies in teaching reading in order that the learners can comprehend what they read in the target language. The appropriate strategies in teaching reading comprehension, therefore, should be implemented by the English teachers in learning activities especially for the EFL learners, because applying good strategies in teaching and learning process may improve students' reading comprehension achievement.

Reading is an important skill and a key success for a student to learn. It is one of the four main skills of language learning. It is a process of getting comprehension of written text. It is a complex process of decoding symbols which purposes to gain understanding. Through reading a students can increase vocabulary, improve memory and enhance knowledge. Since, it gives information about everything such as ideas, values and data which could be important to support their study. The success and failure of a student depends on his or her reading habit or on how many written texts students read. According to Richard (2002:273) there are many reasons for students reading of a second or foreign language: they went to able to read for information and pleasure, for career, and for their study purposes. That is why reading as a key for student's success and a fundamental skill for learning. To develop their academic ability students should read a lot. Academic activities such as studying, writing, discussion, and presentation need reading. Tasks, assignment, exercises, reports and tests can be completed by reading written texts such as notes, text books, journals, scientific reports etc. According to Gebhard (2000:197) reading includes discovering meaning in print and script, within a social context, through bottom-up and top-down processing and the use of strategies and skills. Snow (2002:5-16) states that reading activity is done for several purposes such as completing assignment, recording important information, increasing knowledge and for having pleasure. Through reading a lot students can solve their academic problem and it should be their routine daily activity. Beside reading a lot, students should also have an interest in reading.

Based on the writer's observation, think-aloud is not widely applied at the State Institute for Islamic Studies (IAIN) of Raden Fatah Palembang. Therefore, it seems to the writer that English teaching learning at IAIN Raden Fatah Palembang should be modified from traditional to more current ways. Based on the observation the writer conducted most of the second semester students of Adab Faculty at IAIN Raden Fatah Palembang are still poor in reading comprehension. The writer assumes that the weaknesses in reading comprehension may be caused by the method 
of TEFL, particularly the technique in teaching reading used at the faculty. The traditional technique used at the faculty are : (1) the teacher asks directly their students to read their reading materials, (2) the teacher sometimes reads the text orally, (3) the teacher asks the students whether they found some difficult words in the reading text, (4) the teacher asks the students one by one to read the reading text loudly paragraph by paragraph and translate it into Bahasa Indonesia, (5) the teacher explains the function of grammar that is found in some sentence of the reading text, and (6) the teacher asks the students to answer the reading comprehension questions. Beside, the strategy can enhance students' reading interest. By noticing to students interest, the teachers may increase students motivation to be successful readers. Therefore, the writer is interested in conducting a study entitled "The Influence of Think-Aloud Strategy and Reading Interest Towards Reading Comprehension of the Second Semester Students of Adab Faculty IAIN Raden Fatah Palembang."

\section{Formulation of the Problem}

From the background above, the problem can be formulated as follows:

(1) Is there any significant difference in reading comprehension achievement between the students who are taught by using think-aloud strategy and those who are taught by using conventional strategy?

(2) Is there any significant difference in reading comprehension achievement between the students who are taught by using think-aloud strategy and those who are taught by using conventional technique based on high level in reading interest?

(3) Is there any significant difference in reading comprehension achievement between the students who are taught by using think-aloud strategy and those who are taught by using conventional technique based on low level in reading interest?

(4) Is there any interaction effect of strategies used and taught reading interest on reading comprehension achievement?

\section{Theoretical and Framework of Thinking}

\section{The Concept of Reading}

Reading is a complex interaction between the text and the reader which is shaped by the reader's prior knowledge, experience, attitude and language community which is culturally and socially situated (Wikipedia free encyclopedia) handling much prior knowledge can help a reader in the process of reading especially to comprehend the content of reading text. Accessing prior knowledge to the reading material enables comprehending and saving much reading 
time. Someone's experience, background knowledge and attitude influence the reader very much to derive the meaning of a reading text. As Carrell (1987:24) mentions that everything in the reader's prior knowledge or background experience plays a potential role in the process of reading.

Based on its type, reading can be divided as reading aloud and silent reading. Within silent reading there are extensive and intensive reading. Intensive reading is practicing specific reading strategies or skills. The text is treated as an end in itself. Extensive reading on the other hand, involves reading of large quantities of material, directly and fluently. It is treated as a means to an end. It may include reading simply for pleasure or reading technical, scientific or professional material. This later type of text, more academic, may involve two specific types of reading, scanning for key details or skimming for the essential meaning.

In Cooper et al (1988:32-48) version, types of reading comprehension are divided into 7 elements. All of the elements are organized hierarchically and symbolized by numbers: (1) meaning vocabulary, (2) literal comprehension, (3) inference, (4) main idea, (5) critical reading/thinking, metacognition, and (7) literary application. After analyzing the Lap and Cooper's version in terms of reading comprehension skill, the writer in this study chooses 7 reading comprehension skills which will be tested to the research sample. The reading comprehension skills are (1) details, (2) main idea, (3) reference, (4) inference, (5) vocabulary, (6) sequence, and (7) causeeffect.

\section{The Concept of Reading Interest}

Interest is associates with automatic attention that facilitates learning (Hidi and Renninger, 2006:111). More specifically, such attention frees cognitive resources and leads to more efficient processing and better recall of information. Interest aspect has important role in how interest influences learning. Burn, Betty, and Elinor (1984:23) claim that interest in reading should be considered of prime importance because the more interest the readers have in reading, the more information they get, the more they can understand various kinds of reading materials in the content areas. The reader will do something including drive needed for learning. In this perspective, interest is the fundamental process for reading engagement and is major contributor, when things go away, to disengagement from reading. In addition, according to Schraw, Flowerday and Lehman (2001:211-224), there are three types of interest which reflect different amount of knowledge, value and feeling in reading. They are: (1) situational interest, (2) individual interest, (3) well-developed individual interest. 
Similarly, individual interest has been found to have a positive impact on attention, recognition, and recall, persistence and effort, academic motivation, and levels of learning. According to Hidi and Renninger (2006:111), individual interest is less spontaneous, of enduring personal value, and activated internally. It is a relatively enduring predisposition to experience enjoyment in working with particular subject matter. Individual interest is unique and personal development between the person and a specific topic. This interest can be triggered from good experience, bad experience and even personal relationship. In having these unique experiences they told the students' mind to what they like and what they do not like. So, the students' decision to work on developing his or her knowledge is a choice and would involve effort, would be identified as an individual interest.

\section{The Concept of Think-aloud Strategy}

In this research, it was decided to implement the think-aloud strategy because it was used as an instructional approach, and also because this strategy help readers to comprehend more easily what was being read by them. The think-aloud "as a technique in which students verbalize their thoughts as they read and thus bring into the open the strategies they are using to understand a text", but they are not expected to analyze their behavior as in introspection (Cohen, 1987:
82-95). This metacognitive awareness (being able to think about one's own thinking) is a crucial component of learning, because it enables learners to assess their level of comprehension and adjust their strategies for greater success. By getting students to reflect on the process of thinking aloud as they read, we're encouraging them to recognize the difference between reading the words and comprehending the text.

\section{Think-aloud Procedure}

The think-aloud strategy improves comprehension on test. The teacher will model the think-aloud strategy for students. Below are steps teacher should consider when using think-aloud with students (Glass, C. and Coe-Zygouris, V., 2005:1--5): (1) Chose a short section of text (or a short text). The text should be interesting to students and reflect the content in the classroom. The text should also be challenging and present some difficulty to most of students. Keep in mind the mental processes teacher will be modeling for students. Consider what about the text might cause students problems and select which strategies will model. Give each student a copy of the text. The teacher might also consider projecting a transparency of the text. (2) Introduce the text by explaining that teacher will be modeling a reading strategy, explain why the strategy is important and when the strategy should be used. (3) Read the text out loud and stop often to share teacher 
thinking. Think-aloud the connections are making, the image are creating, the problems having with understanding, and the ways are fixing those problems by the teacher. Tell students explicitly what teacher are doing. The teacher might establish some kind of signal that identifies for students when reading and thinking aloud the processes that are occurring in teacher head. Record teacher thinking on an overhead. (4) After modeling think-aloud a few times, allow students to become more involved in the process. (5) Allow students to try using the think-aloud strategy with a partner. One student should do all the reading and thinking-aloud while the other partner tallies or writes notes about the other student's use of the think-aloud. The teacher should circulate through the room and provide intervention and assistance as needed. Provide a time where students can discuss using the think-aloud strategy with their partner and as a whole class. Another option is to have students reflect on how thinkingaloud has changed their reading habits, this can be done either orally or in writing. (6) The end goal is for students to apply these strategies independently and think in their heads whenever they encounter a text.

\section{RESEARCH METHOD}

This research was conducted through factorial design, an experimental method. The research divides the students reading comprehension scores into two groups: Experimental group and control group. Before both methods, conventional and thinkaloud strategy were implemented, the writer classified the students' reading interest scores into two categories (high and low). Then, the students' pretest and posttest scores were categorized based on the students' reading interest categories and the reading comprehension.

Moderator variable may be either treatment variables or subject characteristics variable (Fraenkel and Wallen, 1990:245). The diagram of factorial design is illustrated in table1 below:

Table 1

Diagram of Factorial Design

\begin{tabular}{|l|lllll|}
\hline Experiment & $\mathrm{R}$ & $\mathrm{O}_{1}$ & $\mathrm{X}_{1}$ & $\mathrm{Y}_{1}$ & $\mathrm{O}_{2}$ \\
Control & $\mathrm{R}$ & $\mathrm{O}_{1}$ & $\mathrm{X}_{2}$ & $\mathrm{Y}_{1}$ & $\mathrm{O}_{2}$ \\
\hline Experiment & $\mathrm{R}$ & $\mathrm{O}_{1}$ & $\mathrm{X}_{1}$ & $\mathrm{Y}_{2}$ & $\mathrm{O}_{2}$ \\
Control & $\mathrm{R}$ & $\mathrm{O}_{1}$ & $\mathrm{X}_{2}$ & $\mathrm{Y}_{2}$ & $\mathrm{O}_{2}$ \\
\hline
\end{tabular}

Source: Fraenkel and Wallen (1990:245)

Where:

$\mathrm{R} \quad=$ Random

$\mathrm{O}_{1}=$ Pretest Score

$\mathrm{O}_{2} \quad=$ Posttest Score

$\mathrm{X}_{1} \quad=$ Think-aloud Strategy

$\mathrm{X}_{2} \quad=$ Conventional Method

$\mathrm{Y}_{1}=$ Students with high reading interest

$\mathrm{Y}_{2}=$ Students with low reading interest

That design related to the study is called $2 \times 2$ designs, and can be illustrated in table 2 below: 
Table 2

2 X 2 Designs

\begin{tabular}{|c|c|c|c|}
\hline & \multicolumn{2}{|c|}{ Strategy } \\
\hline & & $\begin{array}{c}\text { Think-aloud } \\
\left(X_{1}\right)\end{array}$ & $\begin{array}{c}\text { Conventional } \\
\left(\mathbf{X}_{2}\right)\end{array}$ \\
\hline \multirow[t]{2}{*}{$\begin{array}{l}\text { Students' } \\
\text { Reading Interest }\end{array}$} & $\begin{array}{l}\text { High Learning } \\
\text { Interest }\left(\mathrm{Y}_{1}\right)\end{array}$ & & \\
\hline & $\begin{array}{l}\text { Low Learning } \\
\text { Interest }\left(\mathrm{Y}_{2}\right)\end{array}$ & & \\
\hline
\end{tabular}

Source: Fraenkel and Wallen (1990:245)

\section{FINDING OF RESEARCH}

\section{Data Distribution}

The data obtained from the pretest and the posttest scores were presented into two groups. The first group consisted of the pretest scores in the experimental group and in the control group. While, the second group dealt with the posttest scores in the experimental group and in the control group. The data of the students in the pretest both the experimental group and the control group were analyzed to find out the normality and homogeneity of the two samples. While, the data of the students on the posttest both the experimental group and the control groups were analyzed by using two-way ANOVA to find out the interaction between one independent variable (think-aloud strategy) and one moderator variable (reading interest) toward dependent variable (reading comprehension).

\section{a. The Result of the Pre-test Score in the Experimental and Control Groups}

When the data obtained for the experimental group students were analyzed, it was found that there were fifteen students got the score from 30 till $50(43.3 \%)$ and there were fifteen students got the score from 53 till $70(56.6 \%)$. It could be seen from table 12 the pretest score of the experimental group below: 
Table 12

The Pretest Scores of the Experimental Group Pretest_Exp

\begin{tabular}{|ll|r|r|r|r|}
\hline & & Frequency & Percent & Valid Percent & Cumulative Percent \\
\hline Valid & 30 & 1 & 3.3 & 3.3 & 3.3 \\
& 35 & 3 & 10.0 & 10.0 & 13.3 \\
& 38 & 1 & 3.3 & 3.3 & 16.7 \\
40 & 1 & 3.3 & 3.3 & 20.0 \\
& 43 & 1 & 3.3 & 3.3 & 23.3 \\
45 & 3 & 10.0 & 10.0 & 33.3 \\
48 & 1 & 3.3 & 3.3 & 36.7 \\
50 & 2 & 6.7 & 6.7 & 43.3 \\
53 & 2 & 6.7 & 6.7 & 50.0 \\
55 & 3 & 10.0 & 10.0 & 60.0 \\
58 & 6 & 20.0 & 20.0 & 80.0 \\
60 & 1 & 3.3 & 3.3 & 83.3 \\
63 & 4 & 13.3 & 13.3 & 96.7 \\
70 & 1 & 3.3 & 3.3 & 100.0 \\
& & 100.0 & 100.0 & \\
\hline
\end{tabular}

Furthermore, the condition of the students pretest score of the experimental group could

be illustrated in figure 1



(Figure 1: The Frequency of the Pretest Scores of the Experimental Group)

However, pretest was also conducted to the control group students, it could be seen that there were twenty seven students got the scores from 33 till 50 (76.6\%); there were three students of the total number got the score 53 till 63 (23.3\%). It could be seen from table 13 the pretest scores in the control group. 
Table 13

The Pretest Score of the Control Group

Pretest_Ctrl

\begin{tabular}{|ll|r|r|r|r|}
\hline & & Frequency & Percent & \multicolumn{1}{c|}{ Valid Percent } & \multicolumn{1}{c|}{ Cumulative Percent } \\
\hline Valid & 33 & 1 & 3.3 & 3.3 & 3.3 \\
& 35 & 1 & 3.3 & 3.3 & 6.7 \\
& 38 & 1 & 3.3 & 3.3 & 10.0 \\
& 40 & 4 & 13.3 & 13.3 & 23.3 \\
43 & 2 & 6.7 & 6.7 & 30.0 \\
45 & 4 & 13.3 & 13.3 & 43.3 \\
48 & 4 & 13.3 & 13.3 & 56.7 \\
50 & 6 & 20.0 & 20.0 & 76.7 \\
53 & 4 & 13.3 & 13.3 & 90.0 \\
55 & 1 & 3.3 & 3.3 & 93.3 \\
58 & 1 & 3.3 & 3.3 & 96.7 \\
63 & 1 & 3.3 & 3.3 & 100.0 \\
& & 100.0 & 100.0 & \\
\hline
\end{tabular}

Furthermore, the condition of the students

pretest score of the control group could be illustrated in figure 2'

(Figure 2: The frequency of the Pretest Scores of the Control Group)

\section{b. The Result of the Posttest Scores in the Experimental and the Control Groups}

The data from the posttest score of the experimental group was analyzed by using SPSS 17 program. It was found that there were five students who got the scores from 45 till $50(10 \%)$; there were nineteen students got

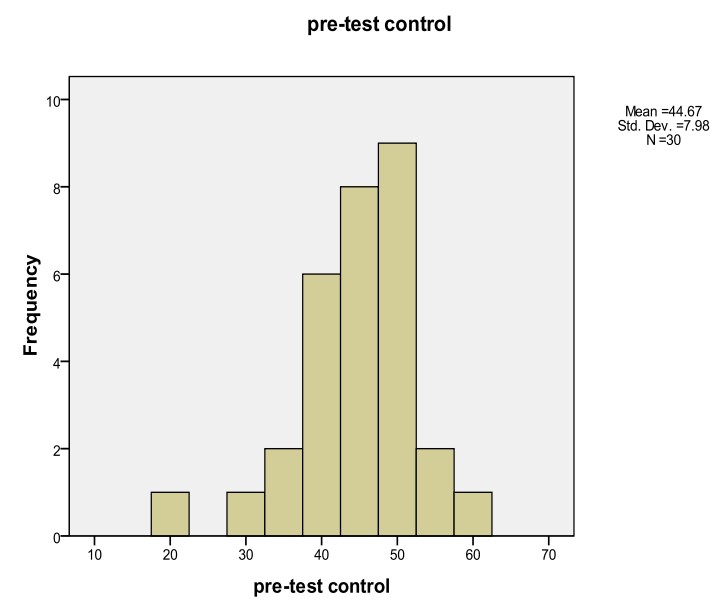

53 till 60 (46.6\%); and there were six students got 63 till $83(43.3 \%)$. The detail could be seen in table 14 . 
Table 14

The Frequency of the Posttest Scores in the Experimental Group

Posttest_exp

\begin{tabular}{|ll|r|r|r|r|}
\hline & & Frequency & Percent & Valid Percent & \multicolumn{1}{c|}{ Cumulative Percent } \\
\hline Valid & 45 & 1 & 3.3 & 3.3 & 3.3 \\
& 48 & 1 & 3.3 & 3.3 & 6.7 \\
& 50 & 1 & 3.3 & 3.3 & 10.0 \\
& 2 & 6.7 & 6.7 & 16.7 \\
& 2 & 3.3 & 3.3 & 20.0 \\
55 & 1 & 10.0 & 30.0 \\
58 & 3 & 10.0 & 26.7 & 56.7 \\
60 & 8 & 26.7 & 13.3 & 70.0 \\
63 & 4 & 13.3 & 10.0 & 80.0 \\
65 & 3 & 10.0 & 10.0 & 90.0 \\
70 & 3 & 10.0 & 6.7 & 96.7 \\
73 & 2 & 6.7 & 3.3 & 100.0 \\
83 & 1 & 3.3 & 100.0 & \\
\hline
\end{tabular}

The figure 3 described the condition of the students in the posttest of the experimental group.

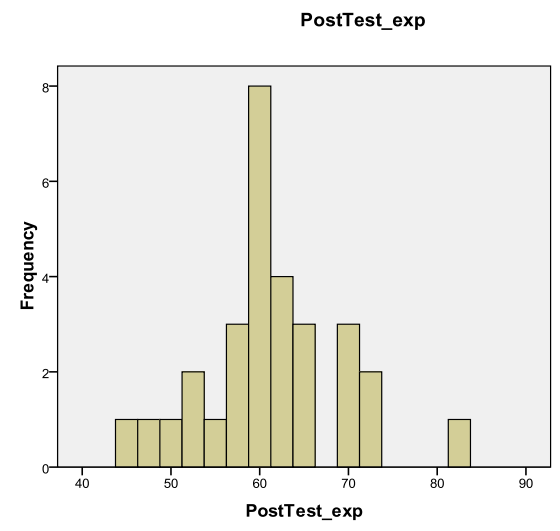

(Figure 3: The frequency of the Posttest Scores of the Control Group)

In this study, the control group also got the same posttest with the same questions. Table 15 showed the frequency, percent, valid percent, and cumulative percent of the posttest score in the control group. It could be seen that in the posttest there were twentyfour students got the score 30 till 50 (50\%); and there were six students got the score 53 till $73(50 \%)$. 
Table 15

The Frequency of the Posttest Scores of the Control Group

PostTest_ctrl

\begin{tabular}{|c|c|c|c|c|c|}
\hline & & Frequency & Percent & Valid Percent & Cumulative Percent \\
\hline \multirow[t]{17}{*}{ Valid } & 30 & 1 & 3.3 & 3.3 & 3.3 \\
\hline & 33 & 1 & 3.3 & 3.3 & 6.7 \\
\hline & 35 & 2 & 6.7 & 6.7 & 13.3 \\
\hline & 38 & 3 & 10.0 & 10.0 & 23.3 \\
\hline & 40 & 2 & 6.7 & 6.7 & 30.0 \\
\hline & 45 & 2 & 6.7 & 6.7 & 36.7 \\
\hline & 48 & 1 & 3.3 & 3.3 & 40.0 \\
\hline & 50 & 3 & 10.0 & 10.0 & 50.0 \\
\hline & 53 & 3 & 10.0 & 10.0 & 60.0 \\
\hline & 58 & 1 & 3.3 & 3.3 & 63.3 \\
\hline & 60 & 5 & 16.7 & 16.7 & 80.0 \\
\hline & 63 & 1 & 3.3 & 3.3 & 83.3 \\
\hline & 65 & 2 & 6.7 & 6.7 & 90.0 \\
\hline & 68 & 1 & 3.3 & 3.3 & 93.3 \\
\hline & 70 & 1 & 3.3 & 3.3 & 96.7 \\
\hline & 73 & 1 & 3.3 & 3.3 & 100.0 \\
\hline & Total & 30 & 100.0 & 100.0 & \\
\hline
\end{tabular}

The figure 4 described the condition of students in the posttest of the control group.

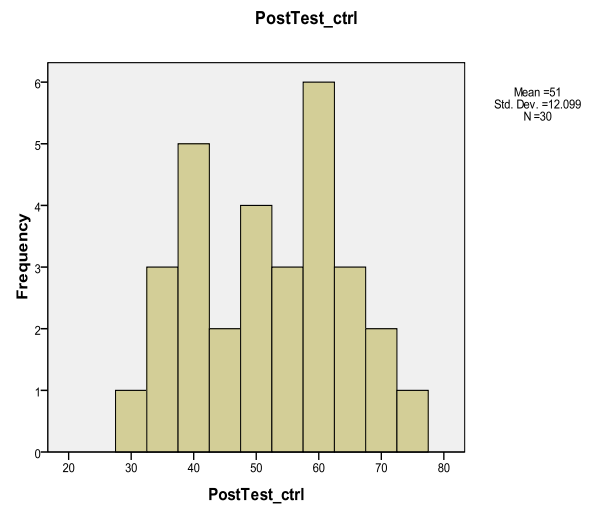

(Figure 4: Frequency of the Posttest Scores of the Control Group)

c. The Scores of the Students' Reading Interest of the Experimental and the Control Groups
In this study, the writer adopted the Harackiewick test (2008) in measuring the students' reading interest in learning English. The questionnaire items reflected the integrative and the instrumental Reading Interest following the Likert Scale System. There were 20 items used to identify students' Reading Interest in learning. It used a 5-point rating scale assessing students' Reading Interest.

According to Gardner and Lambert (1972: 97), in categorizing the level of students' reading Interest, the researcher needed to see the total score obtained by every respondent. The high Reading Interest students were indicated by achieving the score 61-100, while the low Reading Interest 
students were indicated by achieving the score 20-60.

\section{d. The Scores of the students' reading} Interest of the Experimental Group

This table described the frequency, percent, valid percent, and cumulative percent of the experimental group Reading Interest score. This was very important in order to know how many students were in the level of high Reading Interest and in low Reading Interest of the experimental group.

From the table 16 it could be seen that there were fifteen students $(50 \%)$ of the experimental group who had high Reading Interest in learning. In contrast, there were fifteen students $(50 \%)$ of the experimental group who had low Reading Interest in learning.

Table 16

The Scores of the Experimental Group Reading Interest Interest_experiment

\begin{tabular}{|ll|r|r|r|r|}
\hline & Frequency & Percent & Valid Percent & \multicolumn{2}{|c|}{ Cumulative Percent } \\
\hline Valid & 1 & 15 & 50.0 & 50.0 & 50.0 \\
& 2 & 15 & 50.0 & 50.0 & 100.0 \\
& Total & 30 & 100.0 & 100.0 & \\
& & & & \\
\hline
\end{tabular}

The following figure explaining the frequency of students' Reading Interest of the experimental group

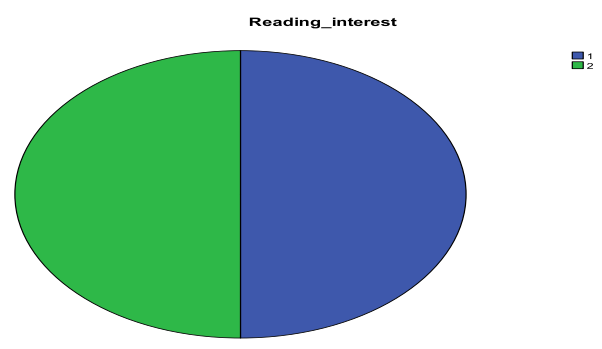

(Figure 5: The Frequency of the Students' Reading Interest of the Experimental Group)

\section{e. The Score of the Students' Reading Interest of the Control Group}

Table 17 explained the frequency, percent, valid percent, and cumulative percent of the control group Reading Interest score. This way very useful in order to know how many students were in the level of high Reading Interest and in the low Reading Interest of the control group. The data of students' Reading Interest in the control group was analyzed by using SPSS, 
Table 17

The Scores of the Control Group Reading Interest

Interest_ctrl

\begin{tabular}{|rl|r|r|r|rr|}
\hline & Frequency & Percent & Valid Percent & \multicolumn{2}{|c|}{ Cumulative Percent } \\
\hline Valid & 1 & 15 & 50.0 & 50.0 & & 50.0 \\
& 2 & 15 & 50.0 & 50.0 & & 100.0 \\
& Total & 30 & 100.0 & 100.0 & & \\
\hline
\end{tabular}

From the table 16 it could be seen that there were fifteen students $(50.0 \%)$ of the control group who had high Reading Interest in learning Reading. In addition, there were fifteen students $(50.0 \%)$ of the control who had low Reading Interest in learning. The following bar chart explained the frequency of students' Reading Interest of the control group.

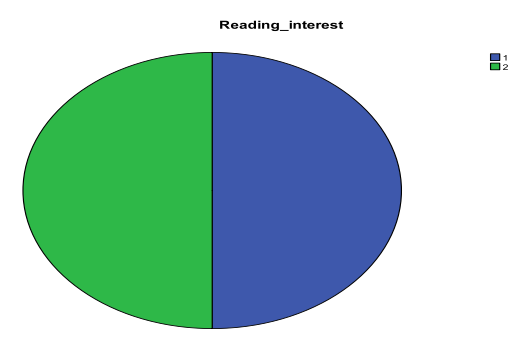

(Figure 6: The frequency of the Students' Reading Interest of the Control Group)

\section{Data Analyses}

In estimating the data collected, three statistical analyses were applied. The analyses were as follows: (1) the statistical on measuring normality of the data, (2) the statistical on measuring homogeneity of the data, and (3) two-way ANOVA.

\section{Statistical Analysis on Measuring Normality of the Data}

Before doing an interference statistic, the test of normality was needed. This was used to find out whether or not the samples taken from the same population (the distribution of the population data) was normal, the result of normality test could be seen in table 18.

Table 18

Tests of Normality

\begin{tabular}{|c|c|c|c|c|c|c|}
\hline & \multicolumn{3}{|c|}{ Kolmogorov-Smirnova } & \multicolumn{3}{|c|}{ Shapiro-Wilk } \\
\hline & Statistic & df & Sig. & Statistic & $\mathrm{df}$ & Sig. \\
\hline $\begin{array}{l}\text { pretest_exp } \\
\text { (Think-äloud) }\end{array}$ & .150 & 30 & .082 & .949 & 30 & .164 \\
\hline $\begin{array}{l}\text { pretest_ctrl } \\
\text { (Conventional) }\end{array}$ & .116 & 30 & $.200^{*}$ & .980 & 30 & .813 \\
\hline
\end{tabular}




\begin{tabular}{|c|c|c|c|c|c|c|}
\hline \multicolumn{7}{|c|}{ Tests of Normality } \\
\hline & \multicolumn{3}{|c|}{ Kolmogorov-Smirnov ${ }^{a}$} & \multicolumn{3}{|c|}{ Shapiro-Wilk } \\
\hline & Statistic & df & Sig. & Statistic & $\mathrm{df}$ & Sig. \\
\hline $\begin{array}{l}\text { pretest_exp } \\
\text { (Think-aloud) }\end{array}$ & .150 & 30 & .082 & .949 & 30 & .164 \\
\hline $\begin{array}{l}\text { pretest_ctrl } \\
\text { (Conventional) }\end{array}$ & .116 & 30 & $.200^{*}$ & .980 & 30 & .813 \\
\hline
\end{tabular}

a. Lilliefors Significance Correction

The result of normality test in Kolmogrov-Smirnov shows the significance value of Think-aloud strategy which was 0.082. Since the significance value of Thinkaloud strategy was higher than 0.05 , it could be called that the distribution sample of Think-aloud was normal. Then, it could also be seen that the significant value of Conventional Strategy in KolmogrovSmirnov was 0.200. This significant value was also higher than 0.05 . It means that the distribution sample of conventional strategy was also normal. Furthermore, the result of normality test in Shapiro-Wilk show the significant value of Think-aloud strategy was 0.164 . This significant value was higher than 0.05 . It could be called that the distribution sample of Think-aloud Strategy in ShapiroWilk was normal. In addition, teaching reading by using conventional strategy has a significant value 0.813 which was also higher than 0.05. It means that the distribution sample of conventional strategy was also normal.

\section{Statistical Analysis on Measuring} Homogeneity of the Data

In estimating whether the data were homogenous, the writer used the test of homogeneity of variance by using SPSS 17 program as could be seen on Table 19 below:

Table 19

Test of Homogeneity of Variances

\begin{tabular}{|c|c|c|c|}
\hline Levene Statistic & df1 & $\mathrm{df2}$ & Sig. \\
\hline 1.525 & 5 & 18 & .232 \\
\hline
\end{tabular}

The result of homogeneity of variance testing indicated that the significant of $\mathrm{p}$ value 0.05 . As it could be seen in Table 18, the significant value was 0.232 . It means that the data were homogeneity in variance. It could be interpreted that the data taken from Think-aloud Strategy and conventional strategy were in homogeneity variance.

3. The Difference Analysis on the Experimental Group and the Control Group Based on Low and High Reading Interest by Using Two-Way ANOVA

In this study, the writer applied twoway ANOVA which is concerned to find out the interaction between one independent 
variable (Mind Mapping Strategy) and one moderator variable (Reading Interest) toward dependent variable (reading comprehension). In this analysis, the writer also investigated whether or not there was any significant difference in reading comprehension achievement for high Reading Interest students and low Reading Interest students taught by using Think-aloud strategy and those who are taught by using Conventional Strategy. The result could be seen on table 20

Group I : Think-aloud Strategy, High Reading Interest

Group II : Think-aloud Strategy, Low Reading Interest

Group III : Conventional Strategy, High Reading Interest

Group IV : Conventional Strategy, Low Reading Interest

Table 20

The Descriptive Statistics of two-way ANOVA Report

Dependent Variable:Reading achievement

\begin{tabular}{|c|c|c|c|c|}
\hline Strategy & $\begin{array}{l}\text { Reading } \\
\text { interest }\end{array}$ & Mean & Std. Deviation & $\mathrm{N}$ \\
\hline \multirow[t]{3}{*}{ Think-aloud } & high & 66.50 & 6.325 & 15 \\
\hline & low & 56.00 & 5.494 & 15 \\
\hline & Total & 61.25 & 7.899 & 30 \\
\hline \multirow[t]{3}{*}{ conventional } & high & 61.00 & 6.395 & 15 \\
\hline & low & 41.00 & 6.931 & 15 \\
\hline & Total & 51.00 & 12.099 & 30 \\
\hline \multirow[t]{3}{*}{ Total } & high & 63.75 & 6.847 & 30 \\
\hline & low & 48.50 & 9.795 & 30 \\
\hline & Total & 56.12 & 11.372 & 60 \\
\hline
\end{tabular}

The output from two-way ANOVA had been given by the writer with a number of tables. Table 19 above shows that group I consist of 15 students, their mean of reading score was 66.50 with standard deviation 6.325; group II consisted of 15 students, their mean of reading posttest score was 56.00 with standard deviation 5.494; Group III consisted of 15 students, their mean score of reading in the posttest score was 61.00 with the standard deviation 6.395; and group IV consisted of 15 students, their mean of reading posttest score was 41.00 with standard deviation 6.931 . From the table above, it could also be interpreted that: First, those students who were taught by using Think-aloud (high Reading Interest and Low Reading Interest), were significantly different in mean score and standard of deviation. Those who had high Reading Interest and taught by using Thinkaloud got 66.50 their mean score and 6.325 as their standard of deviation score, while those who had low Reading Interest and taught by think-aloud got 56.00 as their mean score and 
5.494 as their standard of deviation score. Moreover, the total mean score of students reading comprehension score who were taught by using Think-aloud strategy was 61.25 with standard deviation was 7.899. Second, those students who were taught by using Conventional Strategy (high Reading Interest and Low Reading Interest), were significantly different in mean score and standard deviation. The students who had high Reading Interest and taught by using Conventional Strategy got 61.00 as their mean score and 6.395 as the standard of deviation score, while those who had low Reading Interest and taught by using Conventional
Strategy got 41.00 as their mean score and 6.931 as their standard of deviation score. Furthermore, the total mean score of the students' reading comprehension who were taught by using conventional strategy was 51,00 with standard deviation was 12.099 .

\section{The Interaction Analysis on the Independent Variables}

The influence of variables was described in the following table, such as independent variable (teaching method) and moderator variable (Reading Interest) toward dependent variable (Reading Comprehension).

Table 21

Tests of Between-Subjects Effects

Dependent Variable:Reading achievement

\begin{tabular}{|l|r|r|r|r|r|}
\hline Source & $\begin{array}{c}\text { Type III Sum of } \\
\text { Squares }\end{array}$ & df & Mean Square & F & Sig. \\
\hline Corrected Model & $5402.812^{\mathrm{a}}$ & 3 & 1800.937 & 45.276 & .000 \\
Intercept & 189000.938 & 1 & 189000.938 & 4751.539 & .000 \\
Strategy & 1575.937 & 1 & 1575.937 & 39.620 & .000 \\
Reading_interest & 3488.438 & 1 & 3488.438 & 87.700 & .000 \\
Strategy * Reading_interest & 338.438 & 1 & 338.438 & 8.508 & .005 \\
Error & 2227.500 & 56 & 39.777 & & \\
Total & 196631.250 & 60 & & & \\
Corrected Total & 7630.312 & 59 & & & \\
\hline
\end{tabular}

a. $\mathrm{R}$ Squared $=.708$ (Adjusted $\mathrm{R}$ Squared $=.692$ )

To determine whether there is a main effect for independent variable (Think-aloud Strategy) and moderator variable (Reading Interest) toward dependent variable (Reading Comprehension), it is necessary to check the significance value of each variable. If the value is less than or equal to 0.05 , there is a significance main effect for each variable and if the value is more than 0.05 , there is no significance main effect for each variable. From table 21, it could be seen that F-obtained for Reading Interest was 87.700 with significance value 0.000 . Since the significance value was less than 0.05 , so, 
there was significance different in reading comprehension based on the level of Reading Interest (high and low Reading Interest).

Furthermore, from table 21 it could also be seen that F-obtained for teaching strategy was 39.620 with significance value 0.000. since the significance value was less than 0.05 , so, there was a significance different in reading comprehension based on the strategy applied in teaching reading comprehension.

To find out the interaction effect (influence) of Think-aloud strategy and Reading Interest toward Reading Comprehension depends on whether the students are of high Reading Interest or low Reading Interest, it was necessary to check whether the interaction significant by checking the significance value. If the value is less than or equal to 0.05 , then there is a significance interaction and if the value is more than 0.05 there is no significance interaction. From the sig. column of Table 21, it could be seen that F-obtained was 8.508 with the significance value was 0.005 . it means that there is significant interaction affect (influence) of Think-aloud Strategy and Reading Interest on reading comprehension when it conducted at the same time.

\section{CONCLUSIONS}

Based on the findings and interpretation of the study, the writer draws some conclusion as follows:
1. There was significant different in reading comprehension achievement between the students who were taught by Think-aloud strategy and those students who were taught by using conventional strategy. Therefore, the alternative hypothesis (Ha) was accepted and the null hypothesis (Ho) was rejected.

2. There was significant different in reading comprehension achievement between the students who were taught by using thinkaloud strategy and those who were taught by using conventional technique based on high level in reading interest. Therefore, alternative hypothesis (Ha) was accepted and the null hypothesis (Ho) was rejected.

3. There was significant different in reading comprehension achievement between the students who were taught by using think-aloud strategy and those who were taught by using conventional technique based on low level in reading interest. Therefore, alternative hypothesis (Ha) was accepted and the null hypothesis (Ho) was rejected.

4. There was significant interaction effect (influence) of think-aloud strategy and Reading Interest on Reading Comprehension achievement. Therefore, alternative hypothesis (Ha) was accepted and the null hypothesis (Ho) was rejected. 


\section{References}

Abdillah. 2003. Analisis Buku Rujuka Bahasa Inggris dalam Kurikulum Nasional Perguruan Tinggi Agama Islam untuk Fakultas Tarbiyah. Scholar Jurnal Pendidikan, 4 (1): 9.

Burns, P. C, Betty, D. R, \& Elinor, P, R. 1984. Teaching Reading Today's Elementary School, Boston, MA: Houghton Mifflin. Co.

Carrel. Patricia L. 1987 “A View of Written Text as Communication Interaction: Implications for Reading In a Second Language" Joanne Devine and David E. Eskey. Research in Reading in English as a Second Language. Washington D. C. 23--33

Cooper, J.D., E.W. Warneke, and D.A. Shipman. 1988. The What and How Reading Instruction. Columbus, $\mathrm{OH}$ : Merril Publishing Company.

Gardner. R.C. and Lambert, WE. 1992. Attitude and Reading Interest in Second Language Learning. Rowley Massachusets: Newbury House Publisher.

Gebhard. Jerry G. 2000. Teaching English as a Foreign or Second Language A Teacher Self-development and
Methodology Guide. USA: University of Michigan Press.

Harakiewicz.Judith. Amanda Durik,Kenneth D, Elizabeth L. and John Tauer 2008." The Role of Achievement Goals in the Development of Interest: Reciprocal Relation between Achievement Goals, Interest and Performance". Journal of Educational Psychology. Vol 100. Page 1--62

Hidi, S, \& Renninger, K, A. 2006. The Fourphase, Model of Interest Development. Educational Psychologist, 41 (2), 111--127.

Richard Jack C. 2002. "Teaching Reading" Jack C Richardd and Willy A. Renandya Methodology in Language Teaching an Anthology of Current Practice. New York: Cambridge University Press. 273-275.

Scraw, G, Flowerday, T, \& Lehman, S, 2001. Increasing Situational Interest in the Classroom, Educational Psychology Review, 13 (3), 211--224. Retrieved from www.msu.edu.pdf.

Snow. Catherine. 2002. Reading for Understanding toward and $R \& D$ Program in Reading Comprehension. Santa Monica: RAND. 